\title{
Research on Efficiency Values in Guangzhou Vocational Colleges Based on DEA Model
}

\author{
Aimin Wei ${ }^{1, a}$ \\ ${ }^{1}$ Guangzhou City Construction College, China \\ a524496523@qq.com
}

Keywords: Private vocational; Research capacity; Core thesis; DEA model

\begin{abstract}
This paper uses statistical data that Guangzhou ordinary vocational (specialist) colleges publish core thesis in 2010 and 2013, views the number of full-time teachers and enrollment as input variables, views the number of published core thesis as output variables, and uses DEA model to analyze the efficiency values obtained Guangzhou ordinary vocational (specialist) institutions in general low. Based on this situation, make recommendations for future development in research work about Private Colleges and vocational (specialist) institutions.
\end{abstract}

\section{Introduction}

According to the Ministry of Education published a list of colleges and universities which have a common Higher Education enrollment eligibility in 2013, it shows: A total of 879 regular undergraduate institutions; a total of 1266 general vocational (specialist) institutions; a total of 287 independent colleges approved by the state to set up; a total of 52 validated by the National Arbor school point. Excluding Hong Kong, Macao and Taiwan military academies and universities ${ }^{[1]}$.In terms of scale, general vocational (specialist) institutions accounted for $50.96 \%$ of the total colleges and universities in 2013.In the "National Educational Development Twelfth Five-Year Plan" clearly states: vocational education focus on training industry to upgrade and the development of enterprise technology innovation needs, complex technical skills and innovative talents.

In order to improve vocational colleges opportunity in the current competitive market environment, this paper from the perspective of biblio metrics, viewing VIP "Chinese scientific journals Database" as the data source to search, the analysis and research of Guangdong Province vocational (specialist) institutions published core thesis in 2010-2013, is to provide reference for the research work positioning on Private Vocational Schools.

\section{Guangdong Province common core thesis vocational (specialist) Colleges Statistics}

Use VIP "Chinese scientific journals database" retrieving part of Guangdong Province Vocational Chinese core thesis (specialist) institutions published case in 2010-2013. It is shown as Table 1. 
Table 1 Guangdong Province ordinary vocational (specialist) college papers published core thesis distribution

\begin{tabular}{|c|c|c|c|c|c|c|}
\hline No. & College & 2010 & 2011 & 2012 & 2013 & Subtotal \\
\hline 1 & Shenzhen Polytechnic & 242 & 208 & 217 & 195 & 862 \\
\hline 2 & Guangdong Industry Technical College & 127 & 124 & 128 & 122 & 501 \\
\hline 3 & Shunde Polytechnic & 68 & 62 & 61 & 79 & 270 \\
\hline 4 & Guangdong Food and Drug Vocational College & 74 & 77 & 65 & 64 & 280 \\
\hline 5 & Shenzhen Institute of Information Technology & 71 & 55 & 43 & 60 & 229 \\
\hline 6 & Guangzhou City Polytechnic & 54 & 61 & 51 & 50 & 216 \\
\hline 7 & Guangzhou Panyu Polytechnic & 45 & 48 & 53 & 79 & 225 \\
\hline 8 & Guangdong Institute of Science and Technology & 53 & 52 & 38 & 55 & 198 \\
\hline 9 & Zhongshan Vocational and Technical College & 45 & 50 & 50 & 96 & 241 \\
\hline 10 & Guangdong Technical College of Water Resources & 48 & 44 & 33 & 48 & 173 \\
\hline 11 & Jiangmen Vocational and Technical College & 45 & 46 & 39 & 45 & 175 \\
\hline 12 & Zhongshan Torch Polytechnic & 41 & 32 & 35 & 55 & 163 \\
\hline 13 & Guangdong AIB Vocational and Technical College & 27 & 45 & 46 & 39 & 157 \\
\hline 14 & Guangzhou Railway Vocational and Technical & 23 & 37 & 43 & 29 & 132 \\
\hline 15 & Dongguan Vocational and Technical College & 15 & 31 & 36 & 66 & 148 \\
\hline 16 & Guangdong Polytechnic & 28 & 38 & 37 & 33 & 136 \\
\hline 17 & $\begin{array}{c}\text { Guangdong College of Electrical and Mechanical } \\
\text { Services }\end{array}$ & 33 & 19 & 44 & 32 & 128 \\
\hline 18 & Guangdong Women's Professional Technical & 43 & 31 & 20 & 23 & 117 \\
\hline 19 & College & 28 & 31 & 22 & 34 & 115 \\
\hline 20 & Guangdong Industry \& Trade Polytechnic & 25 & 17 & 30 & 35 & 107 \\
\hline$\sim$ & Qingyuan Polytechnic & $\sim$ & $\sim$ & $\sim$ & $\sim$ \\
\hline 65 & Guangdong Xin'an Vocational and Technical \\
\hline 66 & College * & 1 & 0 & 0 & 0 & 1 \\
\hline
\end{tabular}

Note: (1) 2013 data as of December 31, 2013.

(2) plus * in the institutions is private colleges and vocational (specialist) colleges.

(3) in the table, I chose only some institutions to show the difference between private institutions and national institutions.

(4) because of the limitation of space, we do not listed all in this. We only chose the important data to be make a table.

\section{Data envelopment model}

Calculation of Guangdong Province competitive general vocational (specialist) institutions adopts a non-parametric econometric methods, namely data envelopment analysis (DEA). It does not have to establish functional equations to determine the appropriate parameters, but the use of input-output data sets its own structural characteristics, forming a boundary that contains the efficiency of all data points, the relative efficiency of the border by the best data points (overall efficiency equals 1) linear combination, the remaining points can get the corresponding overall efficiency ratio (ER) by comparison with the linear boundary of this calculation. Clearly, ER range is $0 \leqslant \mathrm{ER} \leqslant 1$. Because this analysis is based on the selected data set.Thus the calculated is the relative value in the overall efficiency of the data structure itself ranges.

Data envelopment analysis first proposed by Charnels, Cooper and Rhodes in 1978, is to evaluate the efficiency and effectiveness of decision making units more than a non-parametric methods. Assuming there are $\mathrm{m}$ inputs, $\mathrm{k}$ outputs, a shared $\mathrm{n}$ sets of data. Let $\mathrm{X}$ be put into a data matrix ( $\mathrm{m}$ $\mathrm{X} \mathrm{n}$ ), $\mathrm{Y}$ be the output data matrix ( $\mathrm{k} \mathrm{X} \mathrm{n).} \mathrm{X}$ and $\mathrm{Y}$ are input and output matrix that matrix desires 
efficient data points, its overall efficiency value by ER solution of the following linear programming problem and get:

The objective function:

$\theta^{*}=\min _{\theta, \lambda} \theta$

Constraints:

$\lambda Y \geq \hat{Y}$

$\theta \hat{X}-\lambda X \geq 0$

$\lambda \geq 0$

Among : $\lambda$ is an $n$-dimensional variable row of the matrix, the overall efficiency of the value of a single variable is the ER required ${ }^{[2][3]}$.

According to the "Guangdong Statistical Yearbook" in the data sheet for the relevant indicators are defined as follows: Output $(\mathrm{k})$ - take the number of core thesis published; input $(\mathrm{m} 1)$ - take the number of full-time teachers, inputs $(\mathrm{m} 2)$ - take the number of admissions quantity.

Overall efficiency:

$\theta=\theta_{T} X \theta_{S}$

Overall efficiency is determined by its technical efficiency and scale efficiency. Evaluation of technical efficiency reflects the ability of an object in the case of a given input for maximum output. Scale efficiency reflects the evaluation of whether the object is in the most appropriate investment scale operations. ${ }^{[4]}$

\section{Computational analysis}

From the Table 1, we can analyze:

Guangdong Province in the top of the general vocational (specialist) School 20 core thesis published from year to see whether the sum or the total look, the basic core of the total published thesis of institutions and the ratio of about $75 \%$, which is the top a quarter of the institutions published nearly three-quarters of the core papers, which is shown as Figure 1.

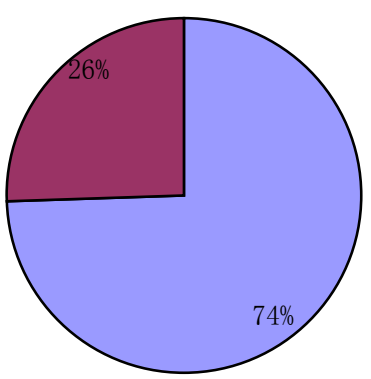

$\square$ The sum of the published thesis in the top of 20

$\square$ The sum of the published thesis in other institutions

Figure 1 the number of published thesis in Front 20 vocational colleges and accounts for proportion(2010-2013)

Guangdong Province in Private Colleges and vocational (specialist) published the core thesis, no matter from year or from the total to see, the proportion is lower than 5\%. Description Guangdong Province Private Colleges and vocational teachers (specialist) research institutions needs to be strengthened, which is shown as Figure 2. 


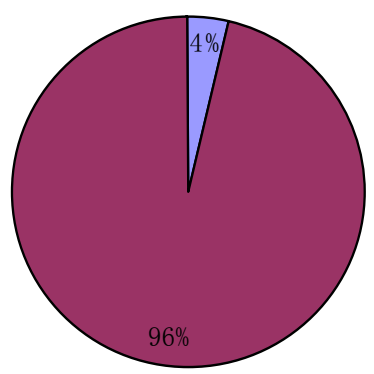

The sum of the published thesis in Private Schools
The sum of the published thesis in other institutions

Figure 2 the sum of the published thesis in Private School and account for proportion(2010-2013)

According to data envelopment analysis model for 2011 Guangzhou ordinary vocational (specialist) institutions to conduct a comprehensive (technical) efficiency analysis, we find that the overall efficiency of Guangdong College of Food and Drug is the highest value , and only 12 ordinary vocational (specialist) the overall efficiency of the institutions is greater than 0.5 , while the overall efficiency of six ordinary vocational (specialist) institutions is equal to zero. Due to space limitations, we do not listed in this.

\section{Conclusions and recommendations}

Through the above analysis of the data can be drawn the following conclusions:

General public vocational (specialist) institutions in Guangdong Province vocational (specialist) core thesis is the main force of the institutions published; Private Colleges and vocational (specialist) Colleges published a very small number of core thesis; Comprehensive analysis of the overall efficiency value Guangzhou ordinary vocational (specialist) institutions, we find that the overall efficiency value in this institutions is very low, especially in private colleges and vocational (specialist) colleges.

In summary, we give the following suggestions:

Private vocational colleges should be given to teachers to create a relaxed, freedom of scientific research and working environment; private vocational colleges should strengthen methodological guidance for teachers scientific research methods and thesis writing, improve the quality of teachers' research and writing skills; should increase research funding investment; should be professional development, curriculum reform and construction, textbook reform and construction, practical teaching base construction as the main research content, highlighting the Private Vocational features.

Private vocational colleges research work can be studied to solve the problem of modern industrial transformation and upgrading and technology innovation in the region as an important issue encountered task.

In government level, government should be proper tilt to private vocational colleges from the institutional development of relevant policies. Various periodicals, magazines should pay attention to teachers in higher vocational colleges and research papers published work, especially private vocational colleges.

\section{Acknowledgements}

The research program has been funded by Guangzhou City Construction College Key project by 2013-2014 year [Z201301]. 


\section{References}

[1] People's Republic of China Ministry of Education.2013 Higher Education has general enrollment eligibility list of colleges and universities. http:/www.moe.gov.cn/publicfiles/ business/ htmlfiles/moe/moe_634/201305/151636.html.

[2] Q.L.Wei. Data envelopment analysis [M].Beijing:Science Pr.2004.

[3] Charnes,A,Cooper,W.W, Rhodes,E.Measurement the efficiency of decision making unit [J].European Journal of Operational Research,1978(2):429-444.

[4] D.B.Ning,Y.Li.Efficiency of China Construction Evaluation Based on DEA Method [J]. Construction Industry,2012 (7). 